\title{
Influence of Goaf on the Slope Stability of the Open-pit Dump
}

\author{
Guoyu Yang, Tao Shang*, Liu Han \\ School of Mines, China University of Mining \& Technology, Xuzhou 221116, China
}

*Corresponding Author: Tao Shang, School of Mines, China University of Mining \& Technology, Xuzhou 221116, China

\begin{abstract}
To study the influence of the surface subsidence caused by goaf on the slope stability of open-pit dump in the process of underground mining, the variation law of surface subsidence range and subsidence amount were analyzed with the outer dump of Haerwusu Open-pit Mine and Suancigou Coal Mine as the research background. The deformation characteristics of the overlying dump induced by goaf were revealed. The results show that as the goaf increases, the surface subsidence area expands and always remains directly above the goaf. The amount of surface subsidence is positively correlated with the height of the goaf. When the height of the goaf is small, the maximum surface subsidence gradually increases with the increase of goaf initially and then becomes stable. The horizontal displacement of the dump slope is not only impacted by the height of the goaf, but also affected by the span of the goaf. The horizontal displacement of the surface above the goaf shows the characteristics of sliding to the middle of the goaf.
\end{abstract}

Keywords: Surface Subsidence; Slope Stability; Goaf; Waste Dump; Numerical Simulation

\section{INTRODUCTION}

With the gradual increase in the proportion of open-pit mining in China's mining area, the safety of open-pit slopes has become more and more prominent [1-2]. Among many factors that affect the stability of the slope, the goaf under the slope resulted from combined mining [3], opencast-tounderground mining[4], and underground mining under the slopes [5] seriously affect the stability of the slope and as a result threaten the safety of personnel and equipment in opencast mines [6].

To explore the law of goaf subsidence, many scholars have used different methods to research it. At present, the research on the subsidence law of the goaf mostly adopts methods that involve monitoring data, mechanical models, similar tests and numerical calculations. Zhang A. B. et al. [7] utilized the chaos theory to analyze the surface subsidence data of the old goaf and found that the surface subsidence is a chaotic system. Jin A. B. et al. [8] used MIDAS/GTS to numerically simulate the settlement of the overlying strata in a certain patch of the mine during the mining process, and the simulation results are found to be relatively close to the actual monitoring data. Qi J. D. et al. [9] conducted monitoring and numerical simulation on the goaf beneath the river and found that the horizontal tectonic stress reduces the maximum settlement, but shows a "sudden" increase in the cumulative settlement. Long L. L. et al. [10] studied the underground mining settlement rules of the Chengchao Iron Mine through monitoring data and three-dimensional numerical values, and found that the shape of the goaf leads to different subsidence laws in different areas of the mining area. $\mathrm{Xu}$ N. Z. et al. [11] used FLAC3D to simulate the surface subsidence stress distribution during coal seam mining in the fault area and found that the original tectonic stress near the fault zone affected by the mining disturbances was released and deformed to a certain extent, with asymmetrical subsidence. Luo R. et al. [12] used 3DEC to simulate the bearing capacity and failure mode of coal pillars, and found that the main reason for the different patterns of surface subsidence is either coal pillar spalling or discontinuous surface slip that destroys the bearing capacity of coal pillars. Li G. et al. [13] established a mathematical model for predicting the surface subsidence range and displacement after coal mining and used FLAC3D to simulate the movement and evolution of rock formations under coal mining conditions in the study area to obtain the amount of surface subsidence and the range of influence. 
In addition, many scholars have conducted extensive research on the influence of goaf on slope stability. Lan H. et al. [14] pointed out that under the influence of mining, the stepped slope body showed obvious "step" distribution and subsidence law. Chai H. B. et al. [15] summarized the influence of goaves located at different positions and different spans on the slope stability. Wang Z. W. [16] studied the influence of underground mining on the slope deformation process of opencast mines through similar simulation tests. Yang X. J. et al. [17] pointed out that when the sliding surface of the slope passes through the goaf, it will seriously affect the stability of the slope. Zhang Z. et al. [18] found that the position of the goaf has the greatest influence on the stability of the slope followed by the goaf span and then the height of the goaf having the least influence through the orthogonal test analysis. These studies have enriched the influence laws of the goaf on the stability of the slope.

The open-pit dump is a geotechnical engineering body formed by a large amount of stripping or tailings generated in the process of open-pit mining [19]. Due to the complexity and low shear strength of the dumped materials, the dump slopes, which are manually stacked and usually high and steep, are more prone to safety issues [20]. Based on the research background of Suancigou Coal Mine and Haerwusu Open-pit Dump, the variation law of the surface subsidence range and the subsidence amount above the goaf were analyzed by the FLAC3D software, and the deformation characteristics of the open-pit dump induced by goaf were revealed in this study.

\section{RESEARCH BACKGROUND}

The Haerwusu Open-pit Coal Mine is located in the east of Xuejiawan Town, Zhungeer Banner, Ordos City, Inner Mongolia Autonomous Region, China. The outer dump of the Haerwusu open-pit mine is located northwest of the ditch in the first mining area, as shown in Figure 1. It covers an area of $5.06 \mathrm{~km}^{2}$, with a height of $100 \sim 120 \mathrm{~m}$, and a final slope angle of $21^{\circ}$. It has been dumped to the boundary and all covered with soil. In addition, Suancigou Coal Mine is a shaft coal mine. The first panel of the mine is located below the outer dump of the Haerwusu Open-pit Coal Mine. The mine mainly mines coal seams 4\# and 6\#. According to the mining design of the Suancigou Coal Mine, there are five working faces 401, 402, 403, 404, and 405 in 4\# coal seam, and six working faces 601, 602, 603, 604, 605, and 606 in 6\# coal seam within the boundary of Haerwusu Outer Dump. At present, the mining of working faces 401,402 , and 403 has been completed. The last working face will end mining in May 2023. 

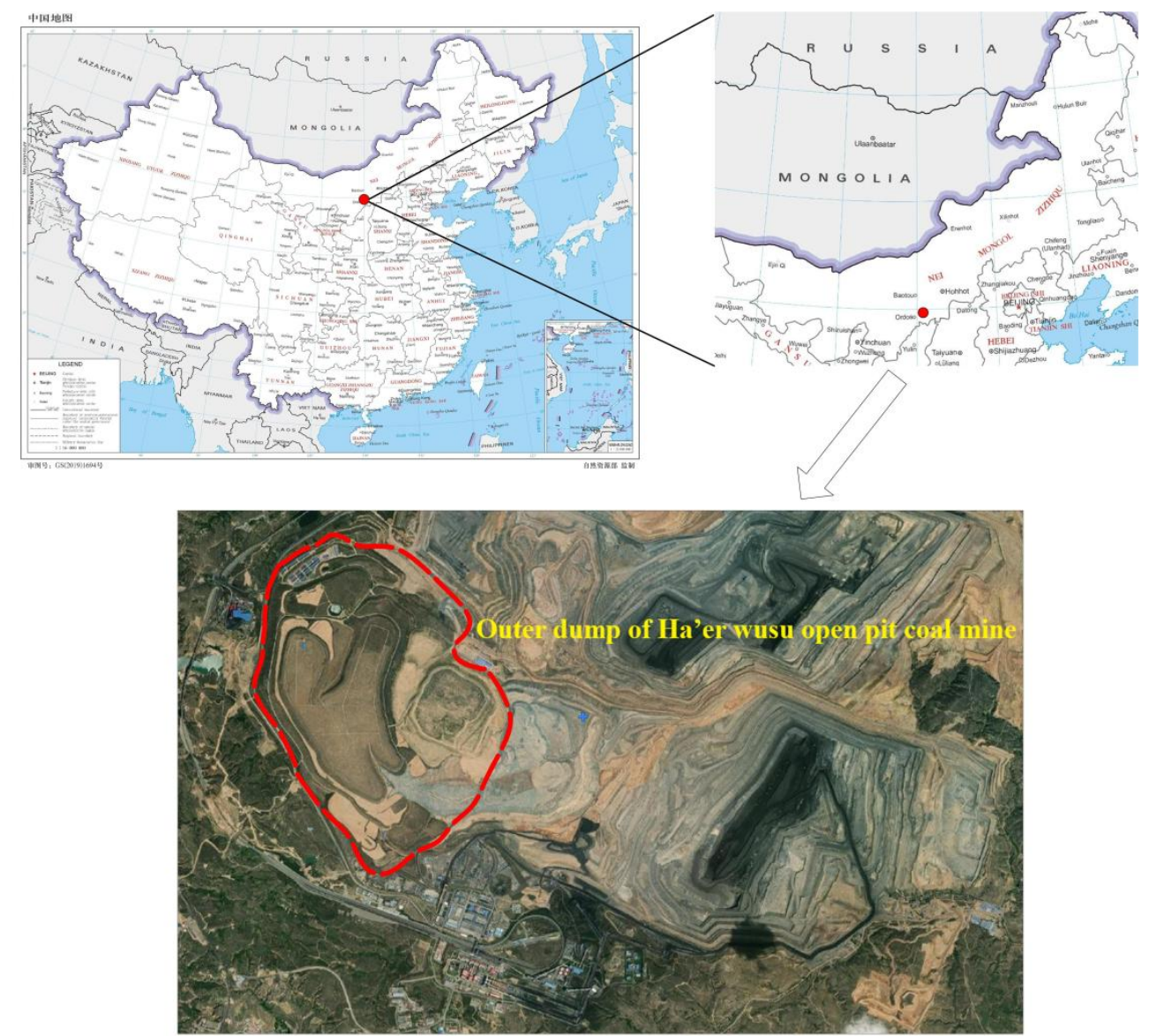

Figure1. The outer dump of Haerwusu Open-pit Coal Mine

Different degrees of subsidence and collapse of the outer dump resulted from mining and a large number of cracks, slips and tilts appeared in some steps after the working faces 401, 402, and 403 of Suancigou Mine. This seriously affected the stability of the outer dump as shown in Figure 2. It is expected that the settlement and cracks in the outer dump will further be aggravated with the subsequent mining of other working faces in the $4 \#$ and $6 \#$ coal seams.

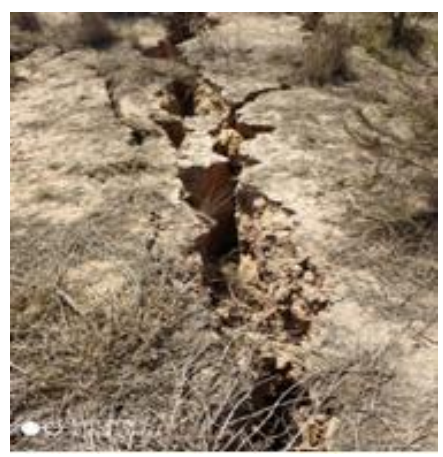

(a) Surface cracks

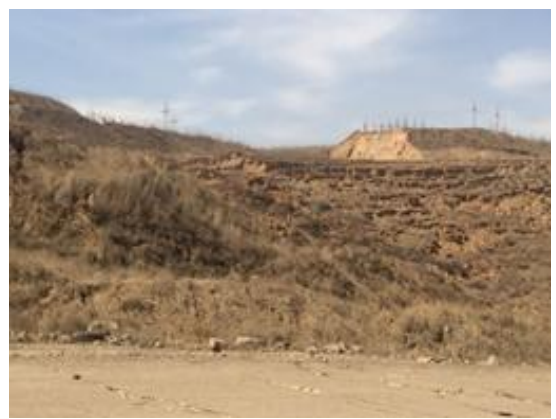

(b) Step settlement 
Figure2. Suancigou mining caused deformation and instability of the outer dump at Haerwusu Open-pit Mine

\section{Materials AND Methods}

In this study, FLAC3D software was used to carry out numerical simulation and to analyze the influence of the Suancigou coal mine goaf on the slope stability of the Haerwusu Open-pit Coal Mine. FLAC3D [21] is a large-scale software for geotechnical engineering professional numerical analysis and has been widely used in the field of slope engineering. To simplify the calculation, an idealized model was constructed with the outer dump of the Haerwusu Open-pit Mine and the first panel of Suancigou Coal Mine as the background, as shown in Figure 3. The dimensions of the model that was constructed using the FLAC3D are $1400 \mathrm{~m} \times 1000 \mathrm{~m} \times 420 \mathrm{~m}$.

The height of the dump slope is $100 \mathrm{~m}$, and the slope angle is $21^{\circ}$. There are 7 steps in the slope. The height of the first step at the top of the slope is $10 \mathrm{~m}$ with a slope angle of $34^{\circ}$. The height of the other 6 steps is all $15 \mathrm{~m}$ with a slope angle of $37^{\circ}$ each. All the flat plates have a width of $20 \mathrm{~m}$. Monitoring points are arranged at the top of each step slope to monitor the displacement in the x-direction. The numbers of monitoring points on the left slope are L1, L2, .., L7 from top to bottom, and the numbers of monitoring points on the right slope are R1, R2, .., R7 from top to bottom.

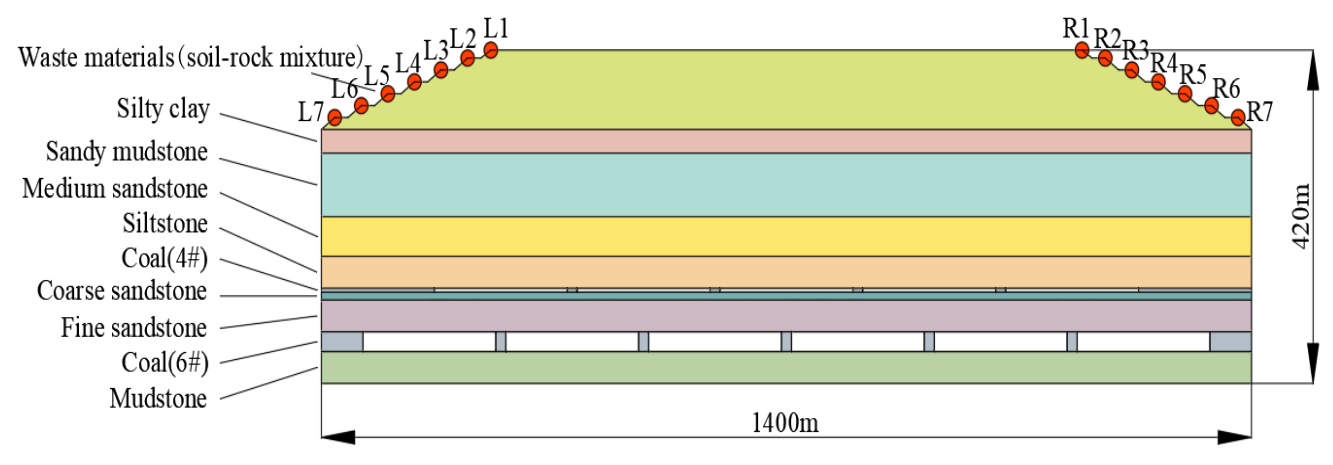

Figure3. The idealized model

The main coal seams under the dump slope are 4\# and 6\# coal seams in the first panel of Suancigou Coal Mine, respectively. The $4 \#$ coal seam has a thickness of $5 \mathrm{~m}$ and a distance of $200 \mathrm{~m}$ from the ground surface, and a total of 5 working faces are arranged, while the 6\# coal seam has a thickness of $25 \mathrm{~m}$ and a distance of $255 \mathrm{~m}$ from the ground surface, and a total of 6 working faces are arranged. The width of all work faces is $200 \mathrm{~m}$, and the distance between two working faces is $15 \mathrm{~m}$. There are a total of 10 rock layers in the model, and the physical and mechanical parameters of each rock layer are shown in Table 1.

Table1. Physical and mechanical parameters of the modeled rocks

\begin{tabular}{|l|l|l|l|l|l|l|}
\hline \multicolumn{1}{|c|}{ Rocks } & $\begin{array}{c}\text { Thickne } \\
\text { ss/m }\end{array}$ & $\begin{array}{c}\text { Bulk } \\
\text { modulus/GPa }\end{array}$ & $\begin{array}{c}\text { Shear } \\
\text { modulus/ GPa }\end{array}$ & $\begin{array}{c}\text { Cohesion// } \\
\text { MPa }\end{array}$ & $\begin{array}{c}\text { Internal } \\
\text { friction angle/ }\end{array}$ & $\begin{array}{l}\text { Density } \\
\text { /kg/m }^{\mathbf{3}}\end{array}$ \\
\hline $\begin{array}{l}\text { Waste materials } \\
\text { (soil-rock } \\
\text { mixture) }\end{array}$ & 100 & 0.19 & 0.07 & 0.0132 & 25 & 1920 \\
\hline Silty clay & 30 & 0.25 & 0.09 & 0.0232 & 21 & 1900 \\
\hline Sandy mudstone & 80 & 4.90 & 1.84 & 4.20 & 40 & 2580 \\
\hline $\begin{array}{l}\text { Medium } \\
\text { sandstone }\end{array}$ & 50 & 4.70 & 1.90 & 6.50 & 46 & 2380 \\
\hline Siltstone & 40 & 4.30 & 1.65 & 17.00 & 15 & 2670 \\
\hline Coal(4\#) & 5 & 2.00 & 0.77 & 2.50 & 35 & 1330 \\
\hline $\begin{array}{l}\text { Coarse } \\
\text { sandstone }\end{array}$ & 10 & 4.20 & 1.64 & 5.30 & 38 & 2360 \\
\hline Fine sandstone & 40 & 7.80 & 3.22 & 11.50 & 44 & 2740 \\
\hline Coal(6\#) & 25 & 2.00 & 0.77 & 2.50 & 35 & 1330 \\
\hline Mudstone & 40 & 4.00 & 1.63 & 8.00 & 35 & 2530 \\
\hline
\end{tabular}

\section{RESULTS AND DISCUSSION}

FLAC3D software was used to simulate the influence of goaf subsidence on the slope stability of the overlying open-pit mine dump. During the simulation process, the 4\# coal seam was first mined 
followed by the $6 \#$ coal seam. When the two seams were mined, the working faces set in the model were all excavated from left to right.

\subsection{The Range and Amount of Surface Subsidence}

To explore the range and amount of surface subsidence during different mining stages, the $\mathrm{z}$ direction displacement nephogram of the model after mining for each working face was selected as shown in Figure 4.

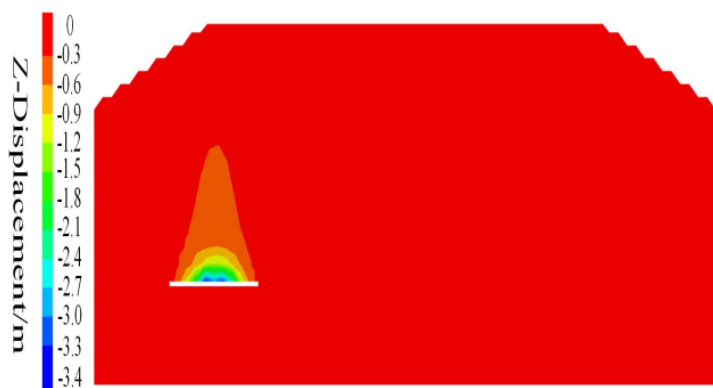

(a). The end of mining at 401 working face

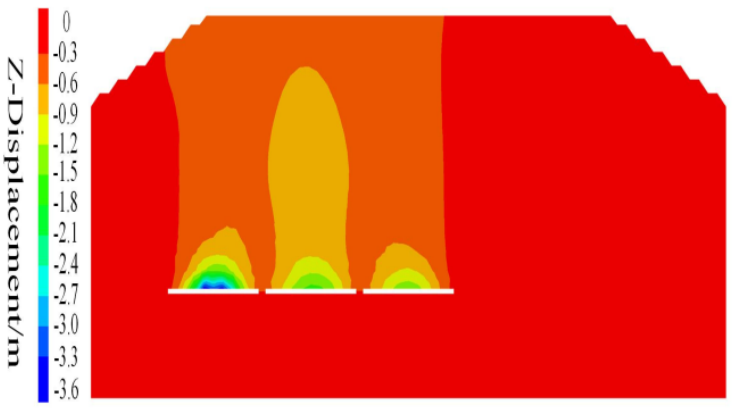

(c). The end of mining at 403 working face

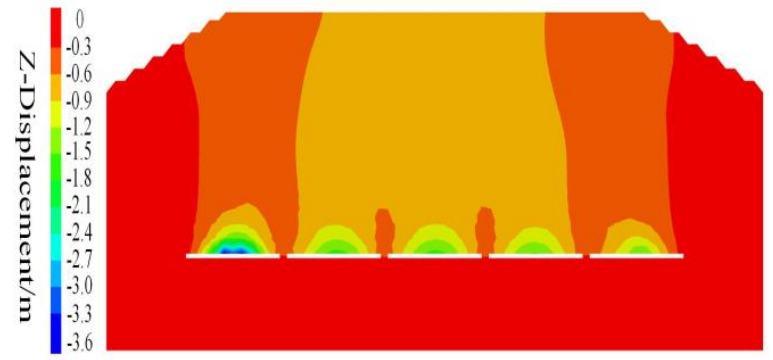

(e). The end of mining at 405 working face

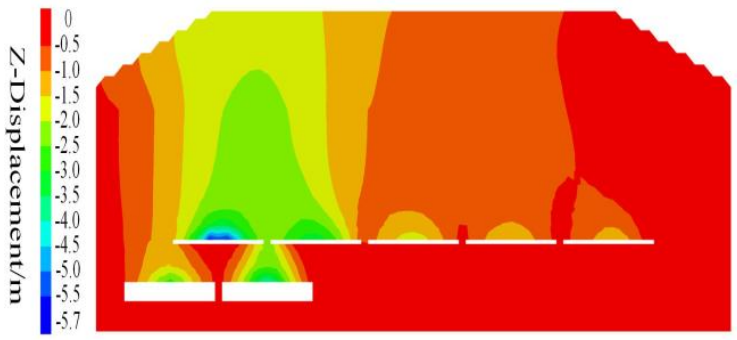

(g). The end of mining at 602 working face

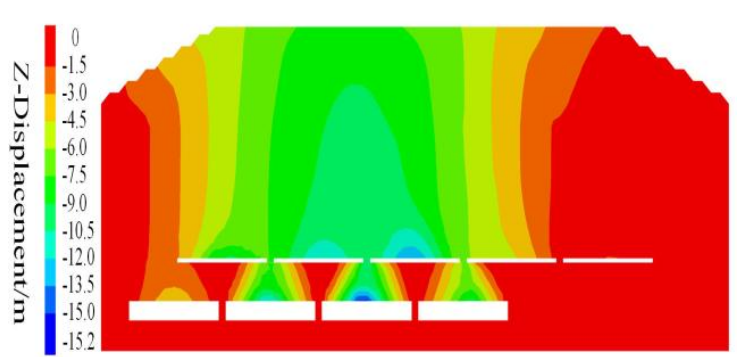

(i). The end of mining at 604 working face

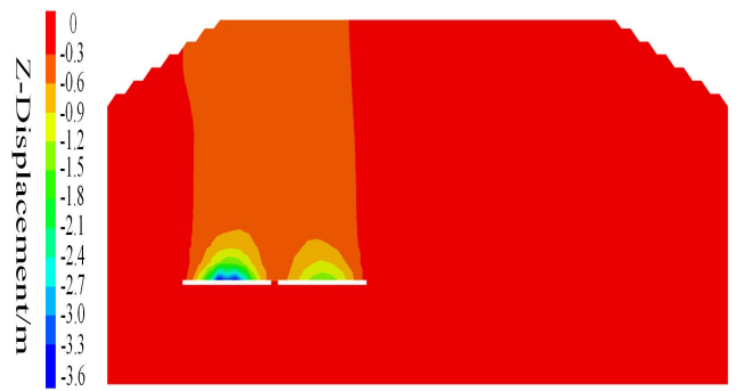

(b). The end of mining at 402 working face

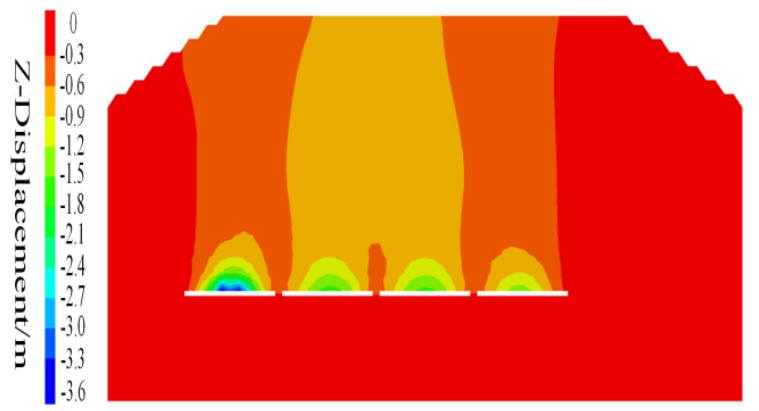

(d). The end of mining at 404 working face

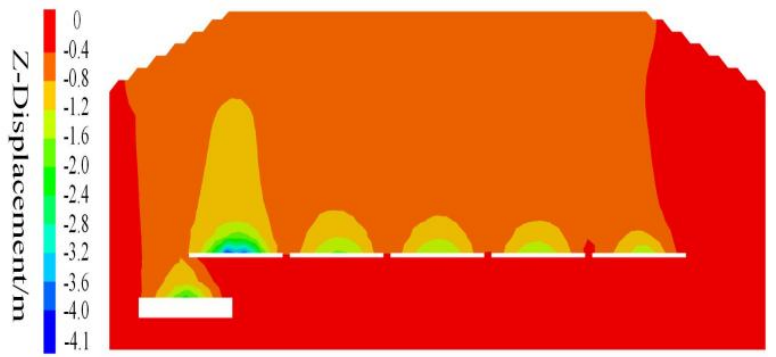

(f). The end of mining at 601 working face

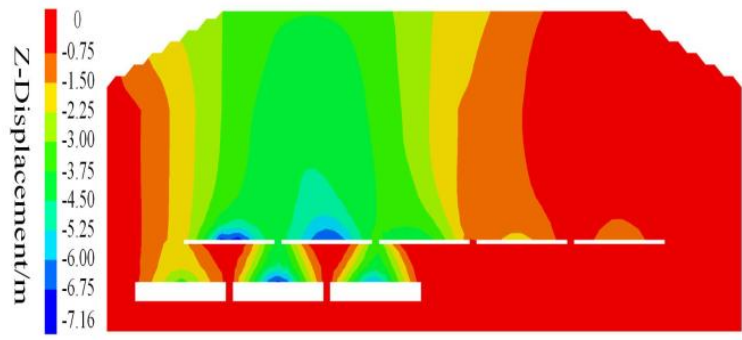

(h). The end of mining at 603 working face

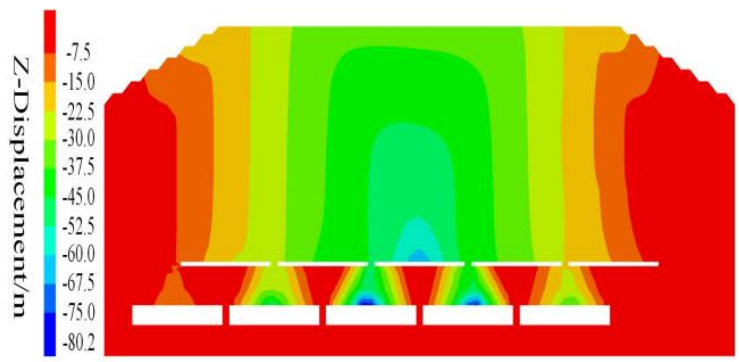

(j). The end of mining at 605 working face 


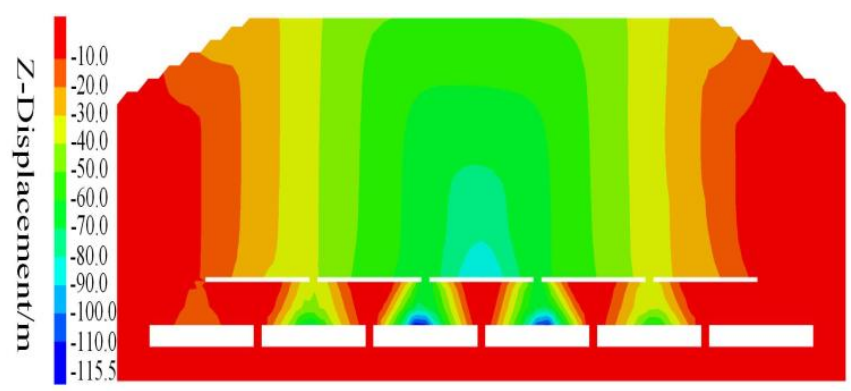

(k). The end of mining at 606 working face

Figure4. Displacement nephogram in the z-direction of the model

Once the mining of 401 working face was completed, the rock above the goaf moved downwards that formed a triangular displacement area having a height of $150 \mathrm{~m}$ with the top slate rock layer in the goaf as the bottom in the z-direction displacement nephogram. After the mining of the 402 working face, the movement of the rock strata developed at the surface causing the movement and deformation of the surface. With the mining of other working faces in the $4 \#$ coal seam, the range of surface subsidence gradually expanded. However, the maximum surface subsidence reached about $0.6 \mathrm{~m}$ and tended to be stable, and did not continue to increase with the subsequent mining of working faces.

Similarly, during the mining of the $6 \#$ coal seam, the movement of the rock gradually developed above the goaf at the surface. At the same time, the surface subsidence area gradually expanded with the increase of the goaf. From the perspective of the overall z-direction displacement area, the movement of the overlying strata and surface subsidence caused by goaf always remained directly above the goaf without developing to the areas outside the edges of both sides of the goaf. The difference is that the overburden displacement and surface subsidence of the $6 \#$ coal seam are much larger than that of the 4\# coal seam goaf. It was attributed to the $6 \#$ coal seam with more height of the goaf after being mined. In addition, after the mining of the $6 \#$ coal seam, the amount of surface subsidence continuously increased, and no stable surface subsidence area was formed.

\subsection{Displacement and Deformation of Soil on the Slope of Dump}

The $\mathrm{x}$-direction displacement can reflect the deformation, displacement and slip trend of the slope soil. The variation curves of the $\mathrm{x}$-direction displacement of the slope monitoring points on both sides with the mining stage are shown in Figure 5.

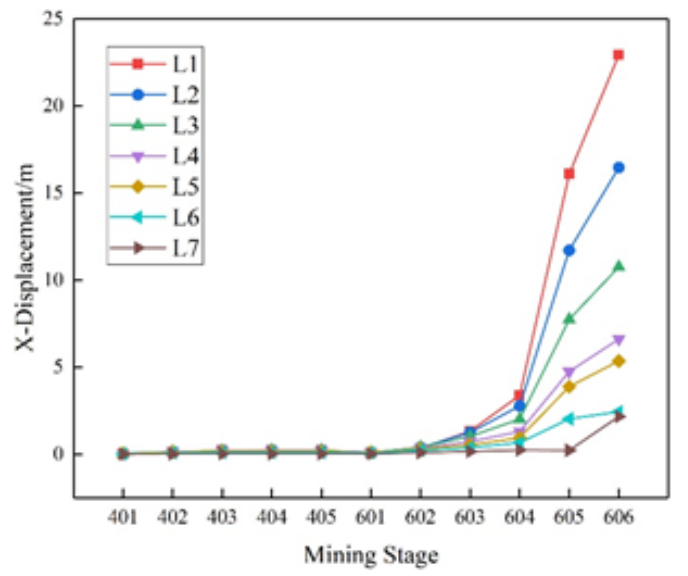

(a). Left side slope monitoring point

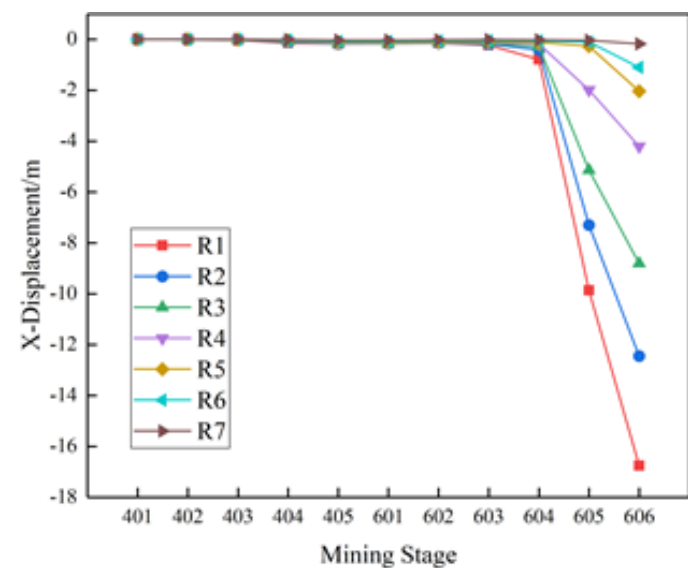

(b). Right side slope monitoring point

Figure5. X-direction displacement of the slope monitoring point

It can be seen from Figure 5 that after the mining of the $4 \#$ coal seam, there was no significant $\mathrm{x}$ direction displacement at all levels of the slopes on both sides because the 4\# Coal seam had a small thickness. Although a certain amount of surface subsidence was caused after the working face was mined to form the goaf, but the obvious slope soil slippage was not generated. After the mining of the 601 working face, no significant $\mathrm{x}$-direction displacement at all levels of slopes on both sides was developed. As the mining advanced for the remaining working faces in the $6 \#$ coal seam, the $x$ displacement of the slopes on both sides increased significantly. This indicated that the stability of the 
slope was not only related to the height of the goaf below the slope, but also affected by the span of the goaf. In addition, the x-displacement of each step from bottom to top gradually increased, and the $\mathrm{x}$-displacement directions of the slopes on both sides were observed to be different. After all working faces were mined, the $\mathrm{x}$-direction displacement of the top steps on the left side slope reached a maximum value of $22.93 \mathrm{~m}$, and the $\mathrm{x}$-direction displacement of the top step on the right-side slope reached a maximum value of $-16.76 \mathrm{~m}$. To explore the reasons for the difference in the $\mathrm{x}$-direction displacement distribution of the slope, the x-direction displacement nephogram after the different mining stages of the 6\# coal seam was selected as shown in Figure 6.

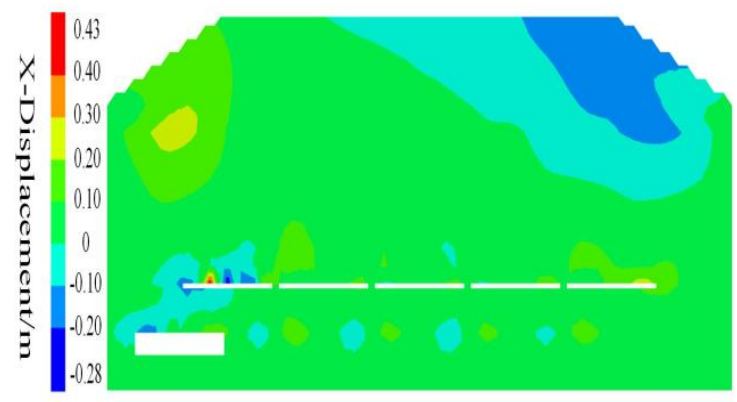

(a). The end of mining at 601 working face

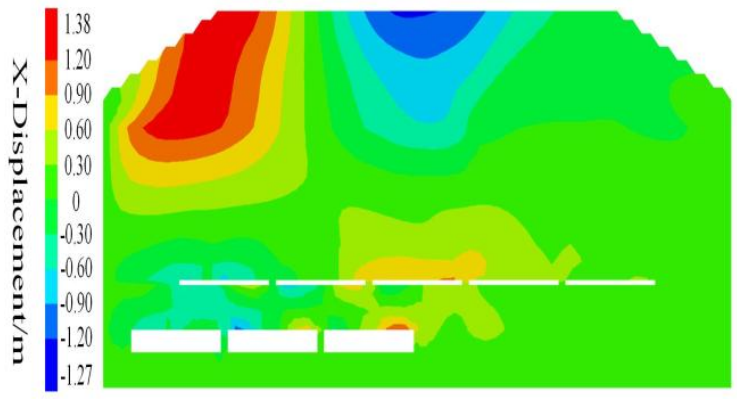

(c). The end of mining at 603 working face

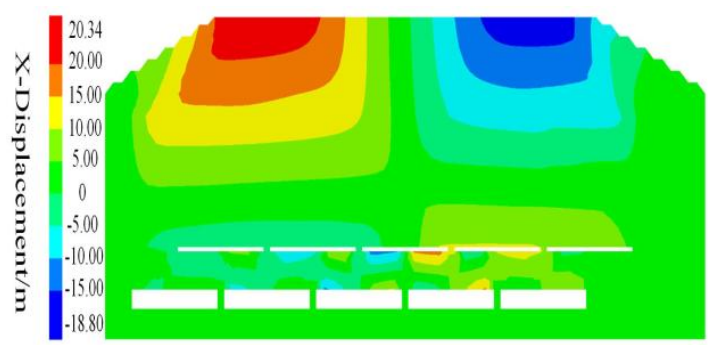

(e). The end of mining at 605 working face

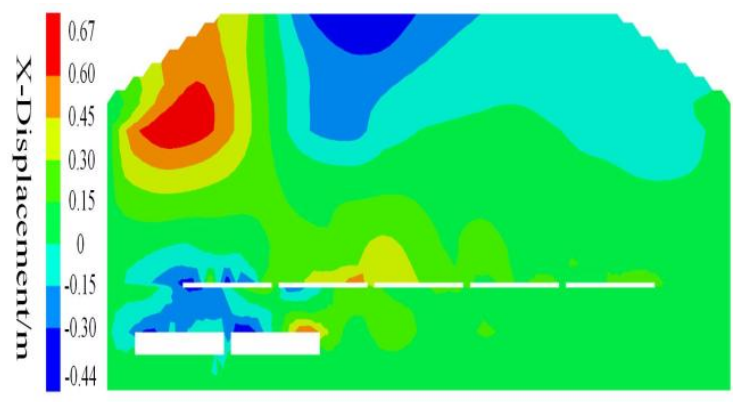

(b). The end of mining at 602 working face

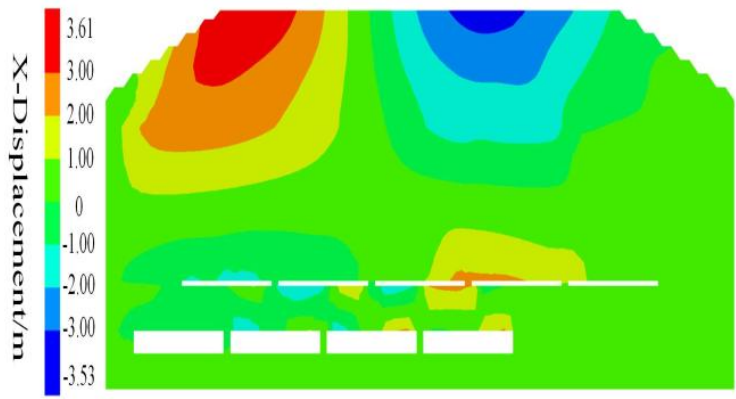

(d). The end of mining at 604 working face

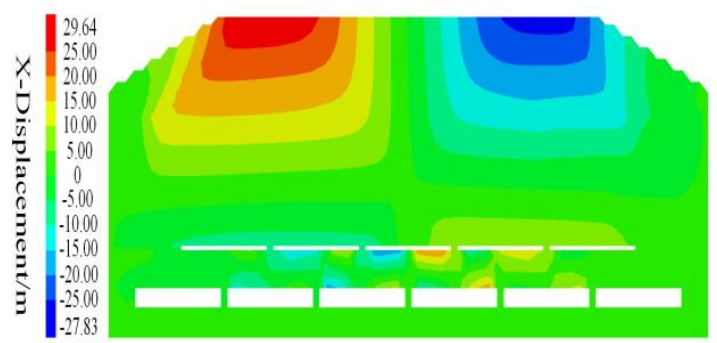

(f). The end of mining at 606 working face

Figure6. Displacement nephogram in the $x$-direction of the model

It can be seen from the $\mathrm{x}$-direction displacement nephogram that after 602 working face was mined, the horizontal displacement on both sides of the 601 and 602 goaves was the largest respectively, and a positive $\mathrm{x}$-direction displacement appeared on the left side of the goaf, and a negative x-direction displacement appeared on the right side of the goaf. As the mining of other working faces in the 6\# coal seam was executed, the displacement areas on both sides of the goaf moved accordingly. It indicated that the surface as a whole shows the characteristics of sliding to the middle of the goaf due to the influence of the goaf. In addition, after all stages of mining, the horizontal displacement on the left side of the goaf was greater than that on the right side, which may be related to the mining sequence of the working face. The goaf that was mined first was disturbed by subsequent mining causing increased movement of the overlying strata, which in turn made the horizontal displacement on the left side of the goaf larger than that on the right as a whole.

\section{CONCLUSiOnS}

Based on the research background of the Haerwusu Open-pit Dump and Suancigou Coal Mine, this study explored the influence of the goaf on the slope stability of the open-pit dump through FLAC3D software. The conclusions are as follows: 
- During the mining process, with the increase of the goaf, the movement of the overlying rock strata gradually develops to the surface and causes surface subsidence. The range of overburden movement and surface subsidence caused by goaf expands with the increase of goaf and always remains directly above the goaf, without developing to the areas outside the edges of both sides of the goaf.

- The amount of surface subsidence caused by the goaf is positively correlated with the height of the goaf. When the height of the goaf is small, the maximum surface subsidence gradually increases with the increase of goaf initially and then tends to be stable.

- The horizontal displacement of the dump slope is not only related to the height of the goaf, but also affected by the span of the goaf.

- The horizontal displacement of the surface above the goaf generally shows the characteristics of sliding to the middle of the goaf. The horizontal displacement on the left side of the goaf is greater than that on the right side, which may be related to the mining sequence of the working face.

\section{ACKNOWLEDGMENTS}

This research was funded by National Key Research and Development Program of China (2016YFC0501103) and National Natural Science Foundation of China (51804298, 51774271).

\section{REFERENCES}

[1] Yang T. H., Wang H., Dong X., et al. Current situation, problems and countermeasures of intelligent evaluation of slope stability in open pit, Journal of China Coal Society. 45(06), 2277-2295 (2020).

[2] Liu S. J., Wu L. X., Mao Y. C., et al. Spaceborne-airborne-ground collaborated intelligent monitoring on open-pit slope and its typical applications, Journal of China Coal Society. 45(06), 2265-2276 (2020).

[3] Zhao Q., Dou Y. J., Huang Q. C. Influence of Mining Method on Stability of Open Pit Slope in the Openunderground Combined Mining Process, Metal Mine. (01), 174-180 (2019).

[4] Liu Y. Z., Liu Y. T., Wu E. Q., et al. Index function analysis method of interlayer thickness for transition time from open pit to underground mining considering slope stability, Journal of Mining \& Safety Engineering. 35(05), 1005-1013 (2018).

[5] Wang C. Y., Li J. P., Liu W., et al. Syudy on Stability of Mining Slope in Different Underground Mining Directions, Mining Research and Development. 38(05), 61-64 (2018).

[6] Xie L. K., Xiong D. Y., Yang T. H., et al. Analysis on disaster impact of concealed goaves underneath open-pit slope and its treatment, The Chinese Journal of Nonferrous Metals. 30(10), 2503-2512 (2020).

[7] Zhang A. B., Gao J. X., Zhang Z. J., et al. Chaotic characteristics and time-variable law of surface subsidence of goaf, Journal of China University of Mining \& Technology. 38(02), 170-174 (2009).

[8] Jin A. B., Ming S. X., Sun J. H. Numerical simulation of surface subsidence and movement law in goaf, Mining Technology. (04), 70-72(2008).

[9] Qi J. D., Gao Y. T., Han H. L. Research on the surface subsidence regularity and treatment technique of goaf underlying river, Metal Mine. (02), 26-31 (2015).

[10]Long L. L., Chen C. X., Xia K. Z., et al. Research on the surface subsidence laws during under ground mining in the west of Chengchao iron mine, Mining Research and Development. 36(07), 47-52 (2016).

[11] Xu N. Z., Gao C. Study on the special rules of surface subsidence affected by normal faults, Journal of Mining and Strata Control Engineering. 2(1), 101-106 (2020).

[12]Luo R., Li G. Y., Chen L., et al. Ground subsidence induced by pillar deterioration in abandoned mine districts, Journal of Central South University. 27(7), 2160-2172 (2020).

[13]Li G., Yang Q. H. Prediction of Mining Subsidence in Shallow Coal Seam, Mathematical Problems in Engineering. 7956947 (2020).

[14]Lan H., Li F. M., Yao J. G. Research on Surface Subsidence of Dump Slope Induced by Mining in Open Colliery, Journal of China University of Mining \& Technology. (04), $482-486$ (2007).

[15] Chai H. B., Cao P., Chai G. W., et al. Influence of goaf on slope stability, Journal of Central South University (Science and Technology). 41(04), 1528-1534 (2010).

[16] Wang Z. W. Experimental study of impact of underground mining on stability of open pit slope, Rock and Soil Mechanics. 35(07), 1843-1848 (2014).

[17] Yang X. J., Geng Q., Liu C. K., et al. Numerical Analysis for the Influnence of Lower Goaf on the Slope Stability, Mining Research and Development. 38(11), 71-74 (2018). 
[18]Zhang Z., Ma N., Liang W. X., et al. Analysis of Influence Factors of Goaf on Slope Stability, Coal Technology. 38(10), 94-96 (2019).

[19] Han L., Shu J. S., Shang T., et al. Experiment study on the physical and mechanical parameters of soft rock remolding in waste dump, Journal of Mining \& Safety Engineering. 36(04), 820-826 (2019).

[20]Ding X. P., Li F. M., Liu B. W., et al. Instability Mode and Control Measures of High Slope in Waste Dump with Bedding Basement, Safety in Coal Mines. 51(7), 244-247 (2020).

[21] Itasca, FLAC3D (Fast Lagrangian Analysis of Continua in 3 Dimensions), Version 5.0. Itasca Consulting Group, Minneapolis, MN, 2012.

Citation: Tao Shang, et.al.(2021)" Influence of Goaf on the Slope Stability of the Open-pit Dump, International Journal of Mining Science (IJMS), 7(2), pp.1-9, DOI: http://dx.doi.org/ 10.20431/24549460.0702001

Copyright: (C) 2021 Authors. This is an open-access article distributed under the terms of the Creative Commons Attribution License, which permits unrestricted use, distribution, and reproduction in any medium, provided the original author and source are credited 